\title{
MAXIMIZING LAND USAGE AND PROFITABILITY BY RELAY INTERCROPPING COTTON WITH SOME CROPS AND ITS RELATION TO INSECT CENSUS
}

\author{
Mohamed M. Lamlom ${ }^{1}$, Mohamed AA Ibrahim ${ }^{2}$, Elham F. Abdel-Rahim ${ }^{3}$ and \\ A.M. Shaker ${ }^{3}$ \\ ${ }^{1}$ Crop Intensification Research Department, Field Crops Research Institute, Agricultural \\ Research Center, Giza Egypt. \\ 2 Agronomy Department, Cotton Research Institute, Agricultural Research Center, Egypt \\ ${ }^{3}$ Plant Protection Research Institute, Agricultural Research Center, Giza Egypt.
}

ABSTRACT

A two-years study was carried out at Sids Agricultural Research Station, Beni-Sweif government, Agricultural Research Center (ARC), Egypt, during 2016/2017 and 2017/2018 seasons to evaluate response of Egyptian cotton traits to different intercropping systems with some wheat cultivars and its relationship with land usage ,farmer's benefit and insect infestation. The treatments were the combination between three wheat cultivars (Sids 4, Sids 12 and Misr 2) and three intercropping systems (wheat/cotton ' $\mathrm{CS}_{1}$ ', wheat + onion (green)/cotton ' $\mathrm{CS}_{2}$ ' and wheat + onion(green) /cotton + sesame ' $\mathrm{CS}_{3}$ '). The treatments were compared in a split plot design with three replications. The results showed that Wheat cultivar Misr 2 gave higher plant, biological and grain yields(10.41, 7.09, 19.71and 18.09) per fad but it had lower grains weight per spike than others in both seasons. Wheat cultivar Sids 4 had higher spike length and weight, grains weight per spike and 1000-grain weight. The cropping system ' $\mathrm{CS}_{1}$ ' had higher grain yield per fad ( 18.89 and 17.44 ardab ) than the other cropping systems in both seasons. The interaction between wheat cultivars and cropping systems significantly affected for all the studied wheat traits in both seasons. Wheat cultivar Misr 2 in cropping system $\mathrm{CS}_{1}$ recorded the highest grain yield (20.50 and 18.31) ardab per fad in both seasons. Meanwhile, the highest spike length and grains weight were obtained by growing wheat cultivar Sids 4 in cropping systems $\mathrm{CS}_{2}$, respectively, in the first season and with wheat cultivar Sids 12 in the second season. Relay intercropping cotton with wheat cultivar Sids 4 had higher seed cotton yield (8.80, 6.86 kintar) per fad than the other cultivars in both seasons. Cropping system $\mathrm{CS}_{1}$ had higher seed cotton yield ( 9.20, 7.14 kintar) per fad than other cropping systems in both seasons. The interaction between wheat cultivars and cropping systems significantly affected for all the studied cotton traits in both seasons hears rely intercropping cotton with wheat cultivar Sids 4 in intercropping CS1 give the highest values for all the studied cotton traits in both seasons. The intercropping had a significant effect on insects, larvae and whole insects. The intercropping resulted in a significant decrease in the number of insects in each of the Jassed, Aphin and the Nezara Viridula in all intercropping systems. Conversely, the intercropping cotton with wheat increased the number of red spider insects, thrips and white flies. In comparison, the intercropping resulted in a significant increase in the number of natural enemies in all intercropping systems in both seasons. while intercropping sesame with cotton also had a significant effect on insects in general, in contrast, this intercropping system had a significant effect on the incidence of almonds worms, where there was

Fayoum J. Agric. Res. \& Dev., Vol. 34, No.1, January, 2020 
MAXIMIZING LAND USAGE AND PROFITABILITY BY RELAY

a significant decrease compared to single cotton in both seasons. on the above, intensive cropping system (Onion + wheat cultivar Sids 4/cotton + sesame) reduced insect incidence compared to the conventional cropping system (wheat/cotton). Relay intercropping cotton with wheat cultivar Sids 4 and intercropping sesame with cotton after wheat harvest $\left(\mathrm{CS}_{3}\right)$ had the highest LER ( 2.81 and 2.64), ATER(1.30 and 1.21) and MAI (LE 23985 and 21194) for the cropping system (Onion + wheat cultivar Sids 4/cotton + sesame)in the first and second seasons, respectively was higher values compared the other treatments in both seasons.

Keywords: Cropping systems; Wheat cultivars; Seed cotton yield; Sesame; Insect incidence; Competitive relationships; Farmers benefit.

\section{INTRODUCTION}

Late cotton (Gossypium baradense L.) planting date is one of the main problems associated with the Egyptian farmers as a result of wheat (Triticum sp.) harvest during the summer season. It is known that cotton plants are liable to be attacked by numerous pests throughout the different stages of plant growth from seedling emergence till harvesting. Thus, late cotton planting date than recommended planting date will lead to changes in insect pest problems that facing cotton in the Nile valley and Delta. Moreover, pesticide misuse and pest resistance, secondary pest outbreaks, as well as, absence or inefficient presence of natural enemies may be contributed largely in insect incidence of cotton plants. Furthermore, cotton cultivated area was about 336 thousand fad in 2018 season (Bulletin of Statistical Cost Production and Net Return, 2018).

Moreover, green stink bug (Nezara viridula $\mathrm{L}$.) caused shedding of formed bolls, yellowing of lint, and reduction in yields (Greene et al. 1999). Furthermore, the sweet potato whitefly, Bemisia tabaci (Gennadius) (Homoptera: Aleyrodidae), is considered one of the most damaging pests of cotton world-wide (Bayhan $\boldsymbol{e t}$ al., 2006). Whitefly infests cotton plants during the period of plant growth season extended from early June to late October with its population peak in August (ElZahi et al., 2012).

On the other hand, wheat is the most important food crop not only in Egypt but also in the word. The national wheat production is insufficient to meet local consumption. So, the selection of an appropriate intercropping system is quite complex as the success of intercropping systems depend much on the interactions between the component species, the available management practices, and the environmental conditions. Several studies showed that relay intercropping cotton with wheat is a successful practice where the crops overlap in time, growing as an intercrop, from March till May (Metwally et al., 2016).

The highest values of number of grains/spike, weight of spike, 1000-grain weight and yield of grains of wheat per fed when cotton was relayed with wheat (Hussein, 2005). In another study, Toaima et al. (2007) found that seed cotton yield was not affected by intercropping with wheat. However, all the intercropping systems increased the quantity of wheat aphids' major natural enemies and the diversities of both predatory and parasitic natural enemies during the outbreak period of wheat aphids (Wang, 2008). Consequently, there is much less agreement about the mechanisms of control measures for some insects that could have a

Fayoum J. Agric. Res. \& Dev., Vol. 34, No.1, January, 2020 
Mohamed M. Lamlom ${ }^{1}$, et al.,

negative effect on intercropped seed cotton yield attributes with wheat. Moreover, the effect of wheat cultivars on seed cotton yield was studied by Sherif et al. (2011) and they reported that wheat cultivars had no marked effect on growth of cotton crop, but wheat cultivar Giza 168 out yielded the other two cultivars. Thus, the effect of wheat cultivars by different intercropping systems could play an important role to increase cotton productivity per unit area with decrease in insect infestation.

On the other hand, intercropping summer field crop as sesame (Sesamum indicum L.) with cotton have been studied by several investigators such as Attia and Seif El Nasr (1993). Rafee (2010) reported that intercropping cotton with sesame resulted in low infestation of thrips (1.93 thrips/leaf) than sole cotton $(2.20$ thrips/leaf). However, intercropping systems significantly affected seed cotton yield Donyavian et al., 2018).

From the other point, onion (Allium cepa L.) thrips (Thrips tabaci, Lindman; Thysanoptera: Thripidae) is a key insect of onion (Alston and Drost, 2008) which is an important insect that reduce onion yield in Egypt. Fortunately, some intercrops may act as barrier crops, some intercrops deter or others may attract insect pests of cotton and some intercrops attract natural enemies of insect pests (Devi, 2018). Onion + cotton was a successful cropping system for seed cotton yield (Lamlom et al., 2018). Therefore, The objectives of this study was to evaluate response of Egyptian cotton traits to insect infestation and its relationship with land usage and farmer's benefit under different intercropping systems.

\section{MATERIALS AND METHODS}

A two-years study was carried out at Sids Agricultural Research Station, Beni Sweif governorate (Lat. $29^{\circ} 12^{\prime}$ N, Long. $31^{\circ} 01^{\prime}$ E, 32 m.a.s.l.), Egypt, during 2016/2017 and 2017/2018 seasons to evaluate response of Egyptian cotton traits to insect infestation and its relationship with land usage and farmer's benefit under different intercropping systems. Table (1) shows soil chemical properties of Sids location before wheat planting, meanwhile soil chemical properties in the cotton rhizosphere at 45 days from cotton planting were shown in Table (2) according to Chapman and Pratt (1961). Soil samples were collected for chemical analysis before adding the first dose of mineral $\mathrm{N}$ fertilizer for cotton plants. Soil texture is clay. Furrow irrigation was the irrigation system in the region. Cultivars of winter field crops there wheat cultivars; Sids 4 'early maturing', Sids 12 'medium maturing' and Misr 2 'late maturing'( Samier and Ismail, 2015, Farahat, 2015 in table 4) and onion cultivar; Giza 6 improved were used. Cultivars of summer filed crops were Giza 95 " extra-long staple" for cotton and Shandweel 3 for sesame.

Fayoum J. Agric. Res. \& Dev., Vol. 34, No.1, January, 2020 
MAXIMIZING LAND USAGE AND PROFITABILITY BY RELAY .69

Table 1. Soil chemical properties of Sids location before wheat planting

\begin{tabular}{|c|c|c|c|c|}
\hline \multirow{2}{*}{ Depth (0-30 cm) } & \multicolumn{4}{|c|}{ Soil chemical properties } \\
\cline { 2 - 5 } & Organic C (\%) & N (ppm) & P (ppm) & K (ppm) \\
\hline Before planting & 0.37 & 30 & 13 & 308 \\
\hline Soil chemical properties in the cotton rhizosphere at 45 days from cotton & planting \\
\hline Depth $(0-30 \mathrm{~cm})$ & Organic C (\%) & $\mathrm{N}(\mathrm{ppm})$ & $\mathrm{P}(\mathrm{ppm})$ & $\mathrm{K}(\mathrm{ppm})$ \\
\hline Intercropping Systems & \multicolumn{4}{|c|}{ Early maturing (Sids 4) } \\
\hline $\mathrm{CS}_{1}$ & 0.98 & 30 & 112 & 256 \\
\hline $\mathrm{CS}_{2}$ & 0.54 & 30 & 196 & 264 \\
\hline $\mathrm{CS}_{3}$ & 0.56 & 30 & 193 & 262 \\
\hline $\mathrm{CS}_{1}$ & 0.70 & 20 & 103 & 216 \\
\hline $\mathrm{CS}_{2}$ & 0.33 & 30 & 128 & 304 \\
\hline $\mathrm{CS}_{3}$ & 0.31 & 30 & 124 & 308 \\
\hline Intercropping Systems $_{\text {Wheat cultivar }}$ & \multicolumn{5}{|c|}{ Late maturing (Masr 2) } \\
\hline $\mathrm{CS}_{1}$ & 0.58 & 20 & 48 & 208 \\
\hline $\mathrm{CS}_{2}$ & 0.33 & 30 & 100 & 272 \\
\hline $\mathrm{CS}_{3}$ & 0.35 & 30 & 99 & 267 \\
\hline Solid cotton planting & 0.78 & 30 & 101 & 196 \\
\hline
\end{tabular}

Note: Soil samples of the cropping system $\mathrm{CS}_{3}$ were taken for chemical analyses before sesame planting.

Calcium super phosphate $\left(15.5 \% \mathrm{P}_{2} \mathrm{O}_{5}\right)$ was applied at rate of $200 \mathrm{~kg} / \mathrm{fad}$ during soil preparation in the two winter seasons. Mineral $\mathrm{N}$ fertilizer was applied at rates $120,75,60$ and $30 \mathrm{~kg} \mathrm{~N} /$ fad for onion, wheat, cotton and sesame, respectively. Mineral $\mathrm{K}$ fertilizer was applied for all the tested crops as recommended for each crop. Table (3) shows sowing and harvest dates of winter and summer field crops in the two growing seasons.

Table 3. Planting and harvesting dates of all the tested field crops

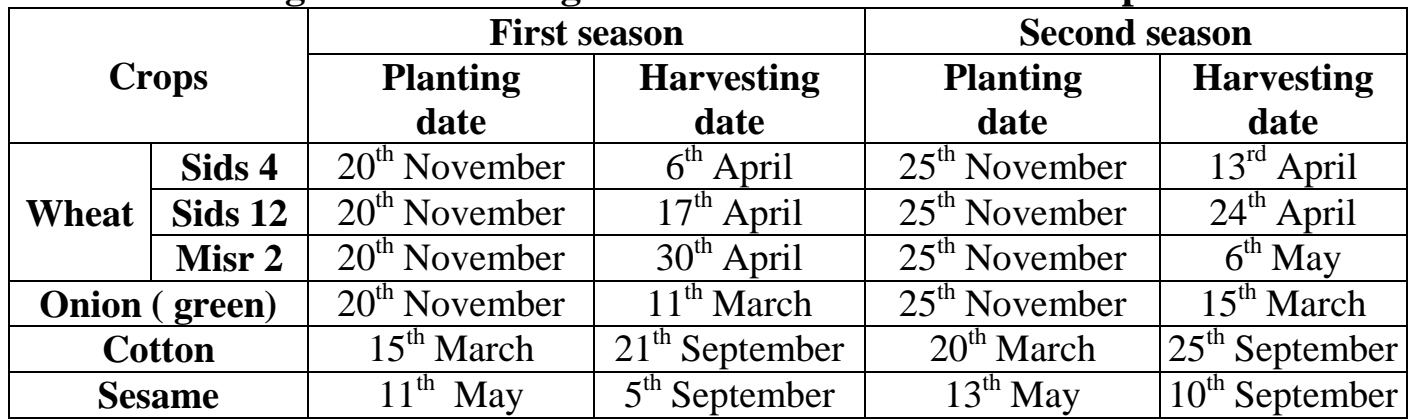

Table( 4 ) name and pedigree of the studied wheat genotypes.

\begin{tabular}{|c|c|c|c|}
\hline Cultivar & Pedigree & $\begin{array}{c}\text { Days to } \\
\text { heading }\end{array}$ & $\begin{array}{c}\text { Days to } \\
\text { maturity }\end{array}$ \\
\hline Sids 4 & MAY"S"MON"S"//CMH74A592/3/GIZA157*2 & 76.20 & 137 \\
\hline Sdis 12 & $\begin{array}{c}\text { BUC//7C/ALD/5/MAYA74/ON//160.147/3/BB/GLL/4/CHAT"S"/6/ } \\
\text { MAYA/VUL//CMH74A.63014*SXSD7096-4SD-1SD-1SD-0SD }\end{array}$ & 99 & 145 \\
\hline Misr 2 & SKAUZ/BAV92 & 105 & 198 \\
\hline
\end{tabular}

Fayoum J. Agric. Res. \& Dev., Vol. 34, No.1, January, 2020 
Mohamed M. Lamlom ${ }^{1}$, et al.,

The treatments were the combination between three wheat cultivars and three intercropping systems (wheat/cotton ' $\mathrm{CS}_{1}$ ', wheat + onion/cotton ' $\mathrm{CS}_{2}$ ' and wheat + onion/cotton + sesame ' $\mathrm{CS}_{3}$ ').

\section{Intercropping patterns:}

- The $\mathrm{CS}_{1}$ (wheat/cotton): wheat grains were grown on beds $120 \mathrm{~cm}$ width in six rows spaced at $15 \mathrm{~cm}$. One row of cotton seeds was grown on both sides of the beds in hills before the last irrigation of wheat, the plants were thinned to two plants per hill distanced at $25 \mathrm{~cm}$ between hills.

- In the $\mathrm{CS}_{2}$ (wheat + onion/cotton). wheat grains were grown on beds $120 \mathrm{~cm}$ width. Onion transplants were grown on both sides of the beds as one plant per hill distanced at $10 \mathrm{~cm}$ between hills. After bulbs uprooting, one row of cotton seeds was grown on both sides of the beds before the last irrigation of wheat, the plants were thinned to two plants per hill distanced at $25 \mathrm{~cm}$ between hills.

- $\quad$ The $\mathrm{CS}_{3}$, intensive cropping system (wheat + onion /cotton + sesame): wheat grains were broadcasted in beds $120 \mathrm{~cm}$ width. Onion transplants were in both sides of beds as one plant per hill distanced at $10 \mathrm{~cm}$ between hills. After bulbs uprooting, one row of cotton seeds was grown on both sides of beds before last irrigation of wheat, the plants were thinned to two plants per hill distanced at $25 \mathrm{~cm}$ between hills. After 45 days from cotton growing, one row of sesame was grown in middle of cotton beds and the plants were thinned to two plants distanced at $20 \mathrm{~cm}$ between hills. In addition to solid plantings of all crops as follows: Wheat: wheat grains were broadcasted on beds $120 \mathrm{~cm}$ width for three cv. (Sids4,12 and Misr-2). Onion: Onion transplants were grown in six rows on beds as one plant per hill distanced $10 \mathrm{~cm}$ between hills. Cotton: Cotton seeds were grown on both sides of beds $120 \mathrm{~cm}$ width after clover (Berseem Fahle), the plants were thinned to two plants per hill distanced at $25 \mathrm{~cm}$ between hills. Sesame: Sesame seeds were grown on the two rows of ridges $120 \mathrm{~cm}$ width, the plants were thinned to two plants per hill distanced at $20 \mathrm{~cm}$ between hills( 70000 plants/fed.).

Nitrogen fertilizer was applied to wheat and cotton in the rate of $65 \mathrm{Kg}$ $\mathrm{N} / \mathrm{fad}$ as ammonium nitrate $(33.5 \% \mathrm{~N})$, and potassium as potassium sulfate $(48 \%$ $\mathrm{K}_{2} \mathrm{O}$ ) by $50 \mathrm{Kg} \mathrm{K} /$ fad were added in three equal dozes; the first dose was applied after thirty days from sowing, the second and third doses were applied before the first and the second irrigation for wheat but it were added in two equal doses for cotton.. Phosphorus as calcium super phosphate $\left(15 \% \mathrm{P}_{2} \mathrm{O}_{5}\right)$ in the rate of $250 \mathrm{Kg}$ $\mathrm{P}_{2} \mathrm{O}_{5} /$ fad was added before planting. Recommended solid plantings of all the tested crops were used to estimate the competitive relationships. Cultural practices for growing all crops were practiced as recommended. A split-plot design with three replications was used. The main plots were devoted to three wheat cultivars, whereas the sub-plots were for intercropping systems. The size of sub-plot was 10.8 $\mathrm{m}^{2}$ (3.0 $\mathrm{m}$ long, and $3.6 \mathrm{~m}$ width for each plot).

\section{The studied traits Wheat crop}

Data of all the traits were recorded on ten guarded plants from each sub plot as follows: plant height $(\mathrm{cm})$, spike length $(\mathrm{cm})$, spike weight $(\mathrm{g})$, grains weight per spike (g) and 1000-grain weight (g). Meanwhile, biological and grain yields per

Fayoum J. Agric. Res. \& Dev., Vol. 34, No.1, January, 2020 
MAXIMIZING LAND USAGE AND PROFITABILITY BY RELAY . .71

fad were weighted and converted to ton and ardab per fad, respectively ( one ardab = $150 \mathrm{Kg}$ )

\section{Cotton crop}

Data of all the traits were recorded on ten guarded plants from each sub plot as follows: plant height $(\mathrm{cm})$, numbers of fruiting branches and open bolls per plant, seed index $(\mathrm{g})$, boll weight $(\mathrm{g})$ and seed cotton yield per plant $(\mathrm{g})$. Meanwhile, seed cotton yield per fad was weighted and converted to kintar per fad ( one kintar cotton seed $=157.5 \mathrm{Kg}$ ).

\section{Onion and sesame crops}

Bulbs and seed yields per fad were weighted and converted to ton for onion and ardab per fad, for seseame (one ardab of sesame $=120 \mathrm{Kg}$ ).

\section{Insect populations}

Twenty five plants from the two replicates were examined from each treatment at 45 days after the planting time (winter and summer) to estimate the seedling insect pests such as; white fly( Bemicia tabaci), Thrips( Thirps tabaci), Jassids( Empoasca lybica), aphids( Aphis gossypii), red spider( Tetraychus telarius) and (Nazara viridula) which recorded as the major pests population densities of the seedling insect pests (early of the season) and its natural enemies such as Aphids lion( Chrysopa pallens), Coccinella spp and Paederus alfierii. Samples of cotton bolls were collected to examine the infestation percent estimate with the bollworms, Earias insulana and Pectionophora gossypiella. Hundred of the mature bolls were collected from intercropped cotton with sesame and cotton solid culture at 45 days from sesame sowing in both seasons. All the data was statistically analyzed by excel window program t-test to calculate the significant differences at 0.05 .

\section{Competitive relationships}

Land equivalent ratio (LER): LER is calculated according to (Mead and Willey, 1980). LER is calculated as follows: $L E R=\left(Y_{a} / Y_{a a}\right)+\left(Y_{b} / Y_{b b}\right)+\left(Y_{c} / Y_{c c}\right)$, where $\mathrm{Y}_{\mathrm{aa}}=$ Pure stand yield of crop a (cotton), $\mathrm{Y}_{\mathrm{bb}}=$ Pure stand yield of crop $\mathrm{b}$ (onion or wheat), $Y_{c c}=$ Pure stand yield of crop c ( sesame), $Y_{a}=$ Intercrop yield of crop a (cotton), $Y_{b}=$ Intercrop yield of crop $b$ (onion or wheat) and $Y_{c}=$ Intercrop yield of crop c (sesame).

Area Time Equivalent Ratio (ATER): ATER determined according to (Hiebsch, 1980),. ATER was calculated by formula: ATER $=R_{y a}(t)+R_{y b}(t)+R_{y c}(t)+R_{y d}(t) /$ Dt Where $R_{y a}, R_{y b}, R_{y c}$, and $R_{y d}$ is Relative yield of crops (wheat, Onion, Cotton, and sesame), $t$ is time taken by crop, $D_{t}$ is time taken by whole system.

\section{Financial evaluation}

Monetary advantage index (MAI) was calculated from the yield of wheat, Onion, Cotton, and sesame in order to measure the productivity and profitability of intercropping as compared to solid planting of the associated component crops. MAI was computed as MAI $=$ (value of combined intercrops) $\times($ LER -1$) /$ LER according to Willey (1979). Crop value in the systems was estimated based on Bulletin of Statistical Cost Production and Net Return ( 2018).

\section{Statistical analysis}

Analysis of variance of the results from each season was performed. The homogeneity test was conducted of error mean squares and accordingly, the analysis

Fayoum J. Agric. Res. \& Dev., Vol. 34, No.1, January, 2020 
Mohamed M. Lamlom ${ }^{1}$, et al.,

of the two experimental seasons was carried out. The data were statically calculated through Excel for windows computer program to determine the F-value, P-value and L.S.D at the lend of at 0.05 of significance). Meanwhile, the measured variables of the tested crops were analyzed by using MSTATC statistical package (Freed, 1991). Mean comparisons were done using least significant differences (L.S.D) method at 5\% level of probability to compare the differences between the means

(Gomez and Gomez, 1984).

RESULTS AND DISCUSSION

Wheat traits

Effect of wheat cultivars

Wheat cultivars significantly differed for all studied traits in both seasons expect, spike weight in the first season and 1000-grain weight in the second one were none (Table 5). With respect to wheat cultivars, wheat cultivar Misr 2 had the highest plant height, biological and grain yield per fad but wheat cultivar Sids 4 gave the highest spike length and weight, grains weight per spike and 1000-grain weight compared to the others. Wheat cultivar Sids 12 produced the shortest plants as compared to the others. These results probably due to genetic potential of the tested wheat cultivars interacted with environmental conditions which reflected on duration of vegetative and reproductive stages that translated finally to economic yield. These results reveal that genetic makeup of wheat cultivar Misr 2 translated into some morphological and physiological characteristics that induced a efficient use of all nutrients by all parts of this cultivar compared to the others. These results are in simelar with El-Kalla et al.(1994) and Nagwa (1995).

Table 5. Effect of wheat cultivars on grain yield and its attributes (2016/2017 and 2017/2018 seasons).

\begin{tabular}{|c|c|c|c|c|c|c|c|}
\hline $\begin{array}{c}\text { Wheat } \\
\text { cultivars }\end{array}$ & $\begin{array}{c}\text { Plant } \\
\text { height } \\
(\mathbf{c m})\end{array}$ & $\begin{array}{c}\text { Spike } \\
\text { length } \\
(\mathbf{c m})\end{array}$ & $\begin{array}{c}\text { Spike } \\
\text { weight } \\
\text { (g) }\end{array}$ & $\begin{array}{c}\text { Grains } \\
\text { weight/ } \\
\text { spike (g) }\end{array}$ & $\begin{array}{c}\text { 1000-grain } \\
\text { weight (g) }\end{array}$ & $\begin{array}{c}\text { Biological } \\
\text { yield/fad } \\
\text { (ton) }\end{array}$ & $\begin{array}{c}\text { Grain } \\
\text { yield /fad } \\
\text { (ardab) }\end{array}$ \\
\hline \multicolumn{7}{|c|}{ First season } \\
\hline Sids 4 & 112.7 & 15.8 & 7.42 & 4.53 & 54.61 & 7.35 & 16.49 \\
\hline Sids 12 & 106.0 & 13.4 & 4.99 & 3.18 & 49.32 & 8.92 & 17.58 \\
\hline Misr 2 & 115.3 & 11.4 & 3.54 & 2.73 & 45.88 & 10.41 & 19.71 \\
\hline L.S.D. 5\% & 4.20 & 2.97 & 1.55 & 0.87 & N.S. & 0.50 & 2.50 \\
\hline \multicolumn{7}{|c|}{ Second season } \\
\hline Sids 4 & 99.78 & 13.23 & 4.49 & 2.01 & 51.98 & 5.23 & 15.67 \\
\hline Sids 12 & 95.89 & 11.34 & 4.95 & 2.68 & 42.86 & 6.99 & 17.34 \\
\hline Misr 2 & 110.78 & 9.64 & 3.61 & 2.07 & 39.92 & 7.09 & 18.09 \\
\hline L.S.D. 5\% & 4.87 & 1.35 & N.S. & 0.59 & 9.77 & 0.41 & 0.86 \\
\hline
\end{tabular}

\section{Effect of cropping systems}

Cropping systems significantly affected plant height, grains weight per spike, biological and grain yields per fad, meanwhile spike length, grains weight and 1000 grain wt. were not affected in the two growing seasons and grain yield per fad in the second season only (Table 6). Cropping system $\mathrm{CS}_{1}$ had the lowest values of plant height, grains weight per spike and biological yield per fad as compared to the others. Meanwhile, cropping system that included onion $\left(\mathrm{CS}_{2}\right.$ and $\left.\mathrm{CS}_{3}\right)$ had the

Fayoum J. Agric. Res. \& Dev., Vol. 34, No.1, January, 2020 
MAXIMIZING LAND USAGE AND PROFITABILITY BY RELAY .73 opposite trend for plant height, grain weight per spike and biological yield per fad. It is important to mention that there were insignificant effects between $\mathrm{CS}_{2}$ and $\mathrm{CS}_{3}$ for plant height, grains weight per spike and biological yield per fad in both seasons. These results may be due to severe competition between wheat plants and cotton for light, water, place and nutritive elements. These results are in accordance with those observed by Hussein (2005).

Table 6. Effect of cropping systems on grain yield and its attributes (2016/2017 and 2017/2018 seasons).

\begin{tabular}{|c|c|c|c|c|c|c|c|}
\hline $\begin{array}{l}\text { Cropping } \\
\text { systems }\end{array}$ & $\begin{array}{l}\text { Plant } \\
\text { height } \\
\text { (cm) }\end{array}$ & $\begin{array}{c}\text { Spike } \\
\text { length } \\
\text { (cm) }\end{array}$ & $\begin{array}{c}\text { Spike } \\
\text { weight } \\
\text { (g) }\end{array}$ & $\begin{array}{c}\text { Grains } \\
\text { weight/s } \\
\text { pike (g) }\end{array}$ & $\begin{array}{l}\text { 1000-grain } \\
\text { weight (g) }\end{array}$ & $\begin{array}{l}\text { Biological } \\
\text { yield/fad } \\
\text { (ton) }\end{array}$ & $\begin{array}{c}\text { Grain yield } \\
\text { /fad } \\
\text { (ardab) }\end{array}$ \\
\hline \multicolumn{8}{|c|}{ First season } \\
\hline $\mathrm{CS}_{1}$ & 109.4 & 12.8 & 5.18 & 3.27 & 48.20 & 8.50 & 18.89 \\
\hline $\mathrm{CS}_{2}$ & 111.7 & 14.0 & 5.16 & 3.44 & 49.71 & 8.92 & 16.74 \\
\hline $\mathrm{CS}_{3}$ & 112.9 & 13.7 & 5.61 & 3.74 & 51.90 & 9.26 & 18.14 \\
\hline L.S.D. 5\% & 2.17 & N.S. & N.S. & 0.32 & N.S. & 0.40 & 1.66 \\
\hline Solid wheat & - & - & - & - & - & 9.62 & 23.53 \\
\hline \multicolumn{8}{|c|}{ Second season } \\
\hline $\mathrm{CS}_{1}$ & 97.56 & 11.5 & 4.26 & 2.00 & 46.99 & 5.94 & 17.44 \\
\hline $\mathrm{CS}_{2}$ & 104.67 & 11.47 & 4.46 & 2.55 & 44.18 & 6.93 & 16.68 \\
\hline $\mathrm{CS}_{3}$ & 104.22 & 11.26 & 4.33 & 2.20 & 43.58 & 6.44 & 16.98 \\
\hline L.S.D. 5\% & 3.78 & N.S. & N.S. & 0.38 & N.S. & 0.51 & N.S. \\
\hline Solid wheat & - & - & - & - & - & 7.30 & 22.65 \\
\hline
\end{tabular}

The interaction between wheat cultivars and cropping systems

The interaction between wheat cultivars and cropping systems had significant effects on all the studied wheat traits in the both seasons (Table 7). Growing wheat late maturing cultivar Misr 2 in cropping system $\mathrm{CS}_{1}$ had higher grain yield per fad(20.50 ardab) than other treatments in both seasons. Six rows of wheat late maturing cultivar Misr 2 that spaced at $20 \mathrm{~cm}$ seems to be played a positive role in intra-specific competition between wheat plants for basic growth resources through soil nutrient availability (Table 2) and biological insect enemies to attack harmful insects of wheat (Table 12). On the other hand, growing wheat cultivar Sids 4 in cropping system $\mathrm{CS}_{1}$ had higher spike length than other treatments in both seasons. It is expected that spike in wheat cultivar Sids 4 that spaced at $20 \mathrm{~cm}$ received its assimilates in a shorter time as a result of lower absorption of soil nutrients which reflected positively on spike length of this cultivar than other treatments. Accordingly, growing wheat cultivar Sids 4 in cropping system $\mathrm{CS}_{2}$ had higher grains weight per spike( $4.89 \mathrm{~g}$ ) as a result of soil nutrient availability because onion plants improved soil quality through its extensive impacts on soil chemical properties than other treatments. These data show that each of these two factors act dependently on all the studied traits of wheat.

\section{Cottton traits}

Effect of Wheat cultivars

Wheat cultivars affected significantly all the studied intercropped cotton traits in the two growing seasons (Table 8). Intercropping wheat cultivar Sids 4 with cotton plants increased significantly number of fruiting branches per plant, seed cotton yields per plant and per fad in the two growing seasons and boll weight in the first season, as well as, plant

Fayoum J. Agric. Res. \& Dev., Vol. 34, No.1, January, 2020 
Mohamed M. Lamlom 1 , et al.,

height, number of open bolls per plant and seed index in the second one compared to others. Conversely, intercropping wheat

Table 7. Effect of wheat cultivars and cropping systems, as well as, their interaction on grain yield and its attributes (2016/2017 and 2017/2018 seasons).

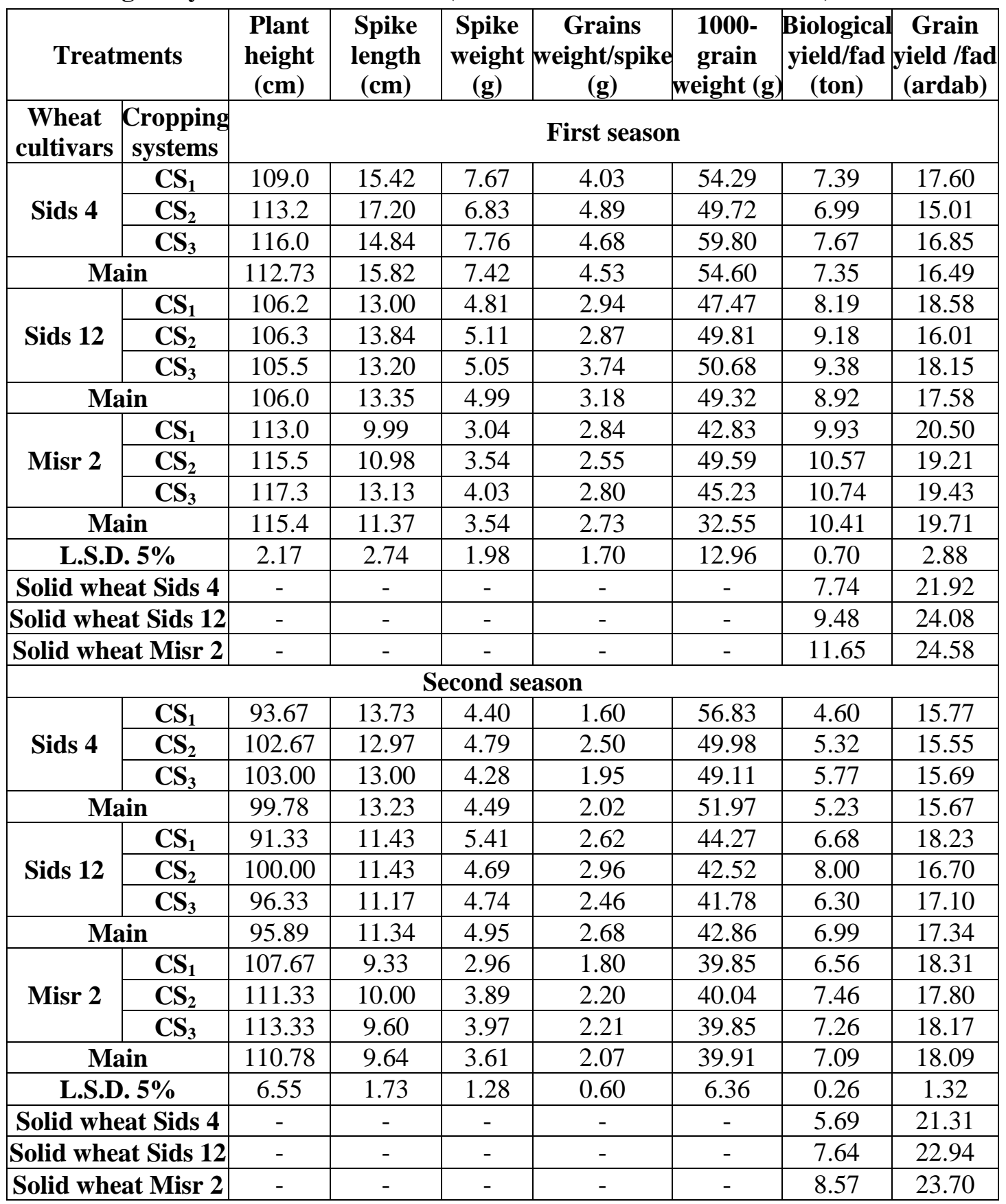

Cultivar Misr 2 with cotton plants caused significant reduction in number of fruiting branches per plant, seed index, seed cotton yields per plant and per fad in the two growing seasons and boll weight in the first season, as well as plant height and number of open bolls per plant in the second one compared to others. These results probably due to wheat cultivar Sids 4 was more compatible with cotton than

Fayoum J. Agric. Res. \& Dev., Vol. 34, No.1, January, 2020 
MAXIMIZING LAND USAGE AND PROFITABILITY BY RELAY .75 wheat cultivar Misr 2 or Sids 12, indicating the shortest vegetative and reproductive stages of wheat cultivar Sids 4 played an important role in furnishing suitable above and under-ground conditions for facilitate pollination process of cotton plant. Moreover, it seems that white flies appeared to be more active in intercropped cotton plants with wheat cultivar Misr 2 or Sids 12 than those intercropped with Sids 4 (Table 10) which reflected positively on growth and development of cotton plants.

Table 8. Effect of wheat cultivars on seed cotton yield and its attributes (2016/2017 and 2017/2018 seasons).

\begin{tabular}{|c|c|c|c|c|c|c|c|}
\hline $\begin{array}{c}\text { Wheat } \\
\text { cultivars }\end{array}$ & $\begin{array}{c}\text { Plant } \\
\text { height } \\
\text { (cm) }\end{array}$ & $\begin{array}{c}\text { No. of Fruit } \\
\text { branches/pla } \\
\text { nt }\end{array}$ & $\begin{array}{c}\text { No. of } \\
\text { open } \\
\text { bolls/plant }\end{array}$ & $\begin{array}{c}\text { Seed } \\
\text { index (g) }\end{array}$ & $\begin{array}{c}\text { Boll } \\
\text { weight } \\
\text { (g) }\end{array}$ & $\begin{array}{c}\text { Seed } \\
\text { cotton } \\
\text { yield } \\
\text { /plant (g) }\end{array}$ & $\begin{array}{c}\text { Seed } \\
\text { cotton } \\
\text { yield /fad } \\
\text { (kintar) }\end{array}$ \\
\hline \multicolumn{7}{|c|}{ First season } \\
\hline Sids 4 & 143.7 & 15.24 & 16.60 & 9.57 & 1.98 & 34.20 & 8.80 \\
\hline Sids 12 & 144.2 & 15.00 & 16.70 & 9.75 & 1.94 & 32.32 & 8.35 \\
\hline Misr 2 & 144.4 & 14.60 & 18.44 & 9.15 & 1.91 & 31.01 & 7.92 \\
\hline L.S.D. 5\% & 0.62 & 0.08 & 0.06 & 0.07 & 0.04 & 0.60 & 0.23 \\
\hline Solid cotton & - & - & - & - & - & - & 10.38 \\
\hline \multicolumn{7}{|c|}{ Second season } \\
\hline Sids 4 & 129.8 & 14.73 & 13.61 & 8.68 & 1.12 & 29.71 & 6.86 \\
\hline Sids 12 & 129.8 & 14.34 & 13.48 & 8.62 & 2.09 & 29.22 & 6.62 \\
\hline Misr 2 & 126.3 & 13.28 & 12.73 & 8.47 & 2.08 & 27.70 & 6.14 \\
\hline L.S.D. 5\% & 0.29 & 0.24 & 0.22 & 0.09 & 0.04 & 0.39 & 0.40 \\
\hline Solid cotton & - & - & - & - & - & - & 10.11 \\
\hline
\end{tabular}

Similar results were obtained by Sherif et al. (2011) they showed that the effect of wheat cultivars on seed cotton yield and they reported that wheat cultivars had no marked effect on growth of cotton crop, but wheat cultivar Giza 168 out yielded the other two cultivars.

\section{Effect of cropping systems}

Cropping systems affected significantly all the studied cotton traits in the two growing seasons except number of open bolls in the first one (Table 9). Cropping system CS, had the highest number of fruiting branches per plant, boll weight, seed cotton yields per plant and per fad in the two growing seasons and plant height, number of open bolls per plant and seed index in the second one compared to others. These results may be due to cotton seedlings benefited greatly from plant growth resources after onion uprooting which reflected on high seed cotton germination, the timely appearance of seedling and the optimum development of root system.

Fayoum J. Agric. Res. \& Dev., Vol. 34, No.1, January, 2020 
Mohamed M. Lamlom ${ }^{1}$, et al.,

Table 9. Effect of cropping systems on seed cotton yield and its attributes (2016/2017 and 2017/2018 seasons).

\begin{tabular}{|c|c|c|c|c|c|c|c|}
\hline $\begin{array}{c}\text { Cropping } \\
\text { systems }\end{array}$ & \begin{tabular}{|c|} 
Plant height \\
$(\mathrm{cm})$
\end{tabular} & $\begin{array}{c}\text { No. of Fruit } \\
\text { branches/plant }\end{array}$ & $\begin{array}{l}\text { No. of open } \\
\text { bolls/plant }\end{array}$ & \begin{tabular}{|c|} 
Seed \\
index $(g)$
\end{tabular} & \begin{tabular}{|c|} 
Boll \\
weight $(\mathrm{g})$ \\
\end{tabular} & \begin{tabular}{|c|} 
Seed cotton \\
yield / plant (g)
\end{tabular} & \begin{tabular}{|c|} 
Seed cotton yield \\
/fad (kintar)
\end{tabular} \\
\hline \multicolumn{8}{|c|}{ First season } \\
\hline $\mathrm{CS}_{1}$ & 143.2 & 15.61 & 16.89 & 9.59 & 2.03 & 35.41 & 9.20 \\
\hline $\mathrm{CS}_{2}$ & 143.8 & 15.10 & 15.94 & 10.09 & 1.91 & 31.84 & 8.16 \\
\hline $\mathrm{CS}_{3}$ & 145.3 & 14.14 & 15.29 & 8.79 & 1.89 & 30.27 & 7.72 \\
\hline L.S.D. 5\% & 0.34 & 0.18 & N.S. & 0.12 & 0.03 & 0.50 & 0.16 \\
\hline Solid cotton & - & - & - & - & - & - & 10.38 \\
\hline \multicolumn{8}{|c|}{ Second season } \\
\hline $\mathrm{CS}_{1}$ & 130.5 & 14.92 & 14.14 & 8.78 & 2.14 & 29.49 & 7.14 \\
\hline $\mathrm{CS}_{2}$ & 129.3 & 14.16 & 13.12 & 8.55 & 2.08 & 29.30 & 6.44 \\
\hline $\mathrm{CS}_{3}$ & 126.0 & 13.28 & 12.56 & 8.44 & 2.07 & 27.83 & 6.04 \\
\hline L.S.D. 5\% & 0.54 & 0.16 & 0.23 & 0.07 & 0.03 & 0.49 & 0.34 \\
\hline Solid cotton & - & - & - & - & - & - & 10.11 \\
\hline
\end{tabular}

Table 10. Effect of wheat cultivars and cropping systems, as well as, their interaction on seed cotton yield and its attributes (2016/2017 and 2017/2018 seasons).

\begin{tabular}{|c|c|c|c|c|c|c|c|c|}
\hline \multicolumn{2}{|c|}{ Treatments } & $\begin{array}{c}\text { Plant height } \\
(\mathrm{cm})\end{array}$ & $\begin{array}{c}\text { No. of Fruit } \\
\text { branches/plant }\end{array}$ & $\begin{array}{c}\text { open } \\
\text { bolls/plant }\end{array}$ & $\underset{(\mathrm{g})}{\text { Seed index }}$ & $\begin{array}{c}\text { Boll } \\
\text { weight (g }\end{array}$ & $\begin{array}{l}\text { Seed cotton } \\
\text { yield /plant } \\
\text { (g) }\end{array}$ & $\begin{array}{c}\text { Seed cotton } \\
\text { yield /fad } \\
\text { (kintar) }\end{array}$ \\
\hline $\begin{array}{l}\text { Wheat } \\
\text { cultivars }\end{array}$ & $\begin{array}{c}\text { Cropping } \\
\text { systems }\end{array}$ & \multicolumn{7}{|c|}{ First season } \\
\hline \multirow{3}{*}{ Sids 4} & $\mathrm{CS}_{1}$ & 142.8 & 15.73 & 17.07 & 9.99 & 2.06 & 36.27 & 9.42 \\
\hline & $\mathrm{CS}_{2}$ & 143.3 & 15.40 & 16.53 & 9.85 & 1.95 & 33.82 & 8.64 \\
\hline & $\mathrm{CS}_{3}$ & 145.0 & 14.60 & 16.23 & 8.86 & 1.92 & 32.52 & 8.36 \\
\hline \multicolumn{2}{|c|}{ Main } & 143.7 & 15.24 & 16.6 & 9.57 & 1.98 & 34.20 & 8.81 \\
\hline \multirow{3}{*}{ Sids 12} & $\mathrm{CS}_{1}$ & 143.2 & 15.60 & 16.87 & 9.71 & 2.03 & 35.19 & 9.21 \\
\hline & $\mathrm{CS}_{2}$ & 143.9 & 15.20 & 16.23 & 10.65 & 1.89 & 31.73 & 8.24 \\
\hline & $\mathrm{CS}_{3}$ & 145.5 & 14.20 & 15.10 & 8.89 & 1.89 & 30.03 & 7.62 \\
\hline \multicolumn{2}{|c|}{ Main } & 144.2 & 15.00 & 16.70 & 9.75 & 1.94 & 32.32 & 8.36 \\
\hline \multirow{3}{*}{ Misr 2} & $\mathrm{CS}_{1}$ & 143.6 & 15.50 & 16.73 & 9.08 & 2.00 & 34.78 & 8.97 \\
\hline & $\mathrm{CS}_{2}$ & 144.3 & 14.70 & 15.07 & 9.77 & 1.88 & 29.98 & 7.60 \\
\hline & $\mathrm{CS}_{3}$ & 145.4 & 13.63 & 14.53 & 8.60 & 1.85 & 28.27 & 7.17 \\
\hline \multicolumn{2}{|c|}{ Main } & 144.43 & 14.61 & 15.44 & 9.15 & 1.91 & 31.01 & 7.91 \\
\hline \multicolumn{2}{|c|}{ L.S.D. 5\% } & 0.60 & 0.18 & 0.09 & 0.21 & 0.06 & 0.86 & 0.28 \\
\hline \multicolumn{2}{|c|}{ Solid cotton } & - & - & - & - & - & - & 10.38 \\
\hline & \multicolumn{8}{|c|}{ Second season } \\
\hline \multirow{3}{*}{ Sids 4} & $\mathrm{CS}_{1}$ & 130.8 & 15.67 & 14.30 & 8.84 & 2.17 & 30.24 & 7.49 \\
\hline & $\mathrm{CS}_{2}$ & 129.3 & 14.30 & 13.30 & 8.60 & 2.10 & 29.55 & 6.65 \\
\hline & $\mathrm{CS}_{3}$ & 129.3 & 14.23 & 13.23 & 8.59 & 2.08 & 29.33 & 6.45 \\
\hline \multicolumn{2}{|c|}{ Main } & 129.8 & 14.73 & 13.61 & 8.68 & 2.12 & 29.71 & 6.86 \\
\hline \multirow{3}{*}{ Sids 12} & $\mathrm{CS}_{1}$ & 130.5 & 14.67 & 14.23 & 8.80 & 2.13 & 29.17 & 7.05 \\
\hline & $\mathrm{CS}_{2}$ & 129.5 & 14.23 & 13.13 & 8.55 & 2.07 & 29.26 & 6.46 \\
\hline & $\mathrm{CS}_{3}$ & 129.3 & 14.13 & 13.07 & 8.50 & 2.07 & 29.23 & 6.33 \\
\hline \multicolumn{2}{|c|}{ Main } & 129.77 & 14.34 & 13.48 & 8.62 & 2.09 & 29.22 & 6.61 \\
\hline \multirow{3}{*}{ Misr 2} & $\mathrm{CS}_{1}$ & 130.2 & 14.43 & 13.90 & 8.68 & 2.11 & 29.06 & 6.88 \\
\hline & $\mathrm{CS}_{2}$ & 129.2 & 13.93 & 12.93 & 8.50 & 2.07 & 29.10 & 6.20 \\
\hline & $\mathrm{CS}_{3}$ & 119.4 & 11.47 & 11.37 & 8.22 & 2.05 & 24.92 & 5.34 \\
\hline \multicolumn{2}{|c|}{ Main } & 126.27 & 13.44 & 12.73 & 8.47 & 2.08 & 27.69 & 6.14 \\
\hline \multicolumn{2}{|c|}{ L.S.D. 5\% } & 0.93 & 0.28 & 0.40 & 0.11 & 0.06 & 0.93 & 0.85 \\
\hline \multicolumn{2}{|c|}{ Solid cotton } & - & - & - & - & - & - & 10.11 \\
\hline
\end{tabular}

Fayoum J. Agric. Res. \& Dev., Vol. 34, No.1, January, 2020 
For climatic conditions, leaf canopy of onion reduced insect incidence of aphids and formed whole space that is available for cotton seedlings to grew with wheat during the seedling, growth and development stages. Form another point, cotton seedlings benefited greatly from residual effects of onion as reported by Lamlom et al., (2018). This positive situation was continued even by growing sesame with cotton through reducing percent of bollworm larvae infestation than cropping systems $\mathrm{CS}_{1}$ and $\mathrm{CS}_{2}$ (Table 9).

\section{Effect of the interaction between wheat cultivars and cropping systems}

The interaction between wheat cultivars and cropping systems had significant effects on all the studied intercropped cotton traits in the two growing seasons (Table 10), Intercropping cotton plants with wheat cultivar Sids 4 in cropping system $\mathrm{CS}_{1}$ had the highest number of fruiting branches per plant, boll weight, seed cotton yields per plant and per fad in the both seasons compared to others. However, intercropping cotton plants with wheat cultivar Masr 2 in cropping system $\mathrm{CS}_{3}$ had the lowest number of fruiting branches per plant, seed index, boll weight, seed cotton yields per plant and per fad in the two growing seasons and number of open bolls in the second sesone as compared to others. These results probably attributed to short growth duration of wheat cultivar Sids 4 that increased soil nutrient availability (Table 2) integrated positively with sesame to enlargement, filling and maturation of boll development. It is likely that the intercropping sesame with cotton facilitated the natural proliferation of predators and recorded higher populations of Coccinella sp (Table 14), especially after harvest of early maturing wheat cultivar Sids 4, which reflected positively on insect incidence. These data show that wheat cultivars responded differentially to cropping systems for the studied cotton traits.

Insect communities

Winter cropping systems (intercropping cotton with wheat, solid cultures of both crops)

Cropping systems affected significantly insect communities in the two growing seasons except aphids and Nezara viridula in the first season (Table 11). The mean number of aphids significantly differed among cropping systems. The highest number of aphids and jassids were recorded for cotton solid culture, whereas there are no any aphids on wheat crop under intercropping or solid cultures, the reverse was true for white flies and red spider. These results may be due to wheat had negative effects on aphids number in intercropping with cotton. Wheat plants may be increased temperature and relative humidity around cotton plants which reduced aphids number in cotton plants than those of solid one. Relative humidity reached to $74 \%$ and minimum temperature also increased in the mid of April and aphid population dropped down to 1.56 aphids/plant while at the end of April, no counts were observed in field by Khan et al. (2012). Meanwhile, whiteflies and jassids were increased significantly in cotton solid culture than cropping systems as result of lowering relative humidity whereas whitefly and jassids populations are usually negatively correlated with relative humidity (Safdar et al., 2019).

Fayoum J. Agric. Res. \& Dev., Vol. 34, No.1, January, 2020 
Mohamed M. Lamlom ${ }^{1}$, et al.,

It is know that spiders do not tend to respond to tiller density (Greenstone, 2001) and consequently tiller density was lower in intercropping systems than solid one. Hence, red spider has an important role under intercropping culture in reducing aphids number where spiders are generalist predators that prey upon aphids, spiders have several modes of capturing prey (Patterson and Ramirez, 2016). With respect to whitefly, whiteflies secreted abundant honeydew containing metabolized sugars (Naroz et al., 2018) which formed a suitable medium for development of aphids.

The mean number of Chrysopa pallens and coccinellid beetle significantly differed among cropping systems (Table 11). The highest number of Chrysopa pallens was recorded by intercropping cotton with wheat cultivars Sids 4 and Sids 12 , whereas the highest number of coccinellid beetle was recorded by intercropping cotton with wheat cultivar Misr 2 as compared to others. These results may be due to wheat cultivars Sids 4 and Sids 12 are early maturing cultivars that formed cooler environment (adverse effects) which retarded growth of nymphs and larvae of many cotton insects. Consequently, aphids were the major insects which attracted Chrysopa pallens to this environment. From other point, intercropping wheat cultivar Misr 2 with cotton formed suitable environment for increasing coccinellid beetle number under intercropping culture. Wheat cultivar Misr 2 is late maturing cultivar that formed warmer environment for more insects which attracted coccinellid beetle to this environment. In other words, wheat cultivar Misr 2 accelerated growth of nymphs and larvae of cotton insects which attracted coccinellid beetle (Table 11). Similar results were obtained by Tulli et al. (2013) who found that increasing plant diversity enhanced the population of coccinellids. As well as these results are in accordance with Helmi and Rashwan (2013) who found that the wheat cultivar Gemiza-9 appeared to be the most resistant cultivar, while Giza-168 appeared to be the most susceptible one for aphid infestations.

The mean number of the green stink bug (Nezara viridula) significantly differed among cropping systems (Table 11). There is Nezara viridula population in intercropping cotton with wheat cultivar Sids 4 only. The increased soil nutrient availability in rhizoshpere of intercropped cotton roots with wheat cultivar Sids 4 (Table 2) contributed to reduce longevity of Nezara viridula. Thus, it is possible that the colonization preference for soybean over cotton was actually a result of higher food quality in cotton intercropped leaves with wheat cultivar Sids 4 than other wheat cultivars. These insects attracted to leaves of host plants as a result of higher quality micro- and macro-environmental conditions (Bonebrake et al., 2010) and higher quality nutritional resources (Rodrigues et al., 2010).

Fayoum J. Agric. Res. \& Dev., Vol. 34, No.1, January, 2020 
MAXIMIZING LAND USAGE AND PROFITABILITY BY RELAY ...........79

Table 11. Effect of winter cropping systems (intercropping cotton with wheat, solid cultures of both crops) on insect populations (2016/2017 and 2017/2018 seasons).

\begin{tabular}{|c|c|c|c|c|c|c|c|c|}
\hline $\begin{array}{c}\text { Winter ropping } \\
\text { systems }\end{array}$ & Jassids & $\begin{array}{c}\text { White } \\
\text { fly }\end{array}$ & Aphids & $\begin{array}{c}\text { Red } \\
\text { spider }\end{array}$ & $\begin{array}{l}\text { Nezara } \\
\text { viridula }\end{array}$ & $\begin{array}{c}\text { Chrysopa } \\
\text { pallens }\end{array}$ & Coccinella & \begin{tabular}{|c|} 
Paederus \\
alfierii
\end{tabular} \\
\hline \multicolumn{9}{|c|}{ First season } \\
\hline $\begin{array}{c}\text { Intercropping } \\
\text { culture } \\
\text { Sids } 4+\text { cotton }\end{array}$ & $2.1 \pm 0.2 * *$ & $0.35 \pm 0.07 *$ & 0 & $1.4 \pm 0.2 * *$ & 0 & 0 & $0.30 \pm 0.06 * *$ & $0.5+0.07 * *$ \\
\hline Sids $12+$ cotton & $1.38 \pm 0.2 * *$ & $0.5 \pm 0.07 * *$ & 0 & $0.9 \pm 0.08 * *$ & 0 & $0.149 \pm 0.05 * *$ & $0.40 \pm 0.07 * *$ & 0 \\
\hline Misr $2+$ cotton & $1.23 \pm 0.2 * *$ & $0.63 \pm 0.1 * *$ & 0 & $0.70 \pm 0.09 * *$ & 0 & \begin{tabular}{|c|}
0 \\
\end{tabular} & $0.42 \pm 0.07 * *$ & 0 \\
\hline Solid cotton & $3.75 \pm 0.3$ & 0 & 0 & 0 & 0 & 0 & $1.02 \pm 0.1$ & 0 \\
\hline Solid wheat & 0 & 0 & 0 & 0 & 0 & 0 & 0 & 0 \\
\hline L.S.D. $5 \%$ & 0.76 & 0.13 & N.S. & 0.26 & N.S. & 0.10 & 0.25 & 0.14 \\
\hline \multicolumn{9}{|c|}{ Second season } \\
\hline $\begin{array}{c}\text { Intercropping } \\
\text { culture } \\
\text { Sids } 4+\text { cotton }\end{array}$ & $0 * *$ & $0^{\text {n.s }}$ & $0^{* *}$ & $1.5 \pm 0.5^{\mathrm{n} . \mathrm{s}}$ & $0.211 \pm 0.06^{* *}$ & $4.5 \pm 3.5^{* *}$ & $0.75 \pm 0.1^{\mathrm{n} . \mathrm{s}}$ & 0 \\
\hline Sids $12+$ cotton & $0 * *$ & $0^{\text {n.s }}$ & $0 * *$ & $2 \pm 0.6^{\mathrm{n} . \mathrm{s}}$ & 0 & $2 \pm 0.4 * *$ & $1.3 \pm 0.7^{\mathrm{n} . \mathrm{s}}$ & 0 \\
\hline Misr $2+$ cotton & $0 * *$ & $0^{\text {n.s }}$ & $0 * *$ & $2.3 \pm 0.3^{*}$ & 0 & $1.3 \pm 0.3$ & $2 \pm 0.6^{\mathrm{n} . \mathrm{s}}$ & 0 \\
\hline Solid cotton & $3 \pm 0.8$ & $1 \pm 0.6$ & $3.75 \pm 0.5$ & 0 & 0 & 0 & 0 & 0 \\
\hline Solid wheat & 0 & 0 & 0 & 0 & 0 & 0 & 0 & 0 \\
\hline L.S.D. 5\% & 2.40 & N.S. & 1.2 & 1.4 & 0.11 & 1.2 & N.S. & N.S. \\
\hline
\end{tabular}

Table 12. Effect of winter cropping systems (intercropping onion with wheat, solid cultures of both crops) on insect populations (2016/2017 and 2017/2018 seasons).

\begin{tabular}{|c|c|c|c|}
\hline winter croppingsystems & Aphids + thrips & Chrysopa pallens & Coccinella \\
\hline \multicolumn{4}{|c|}{ First season } \\
\hline Sids 4 + onion & $166 \pm 1^{* *}$ & $1.6 \pm 0.2 \mathrm{n} . \mathrm{s}$ & $17.3 \pm 2.4^{* *}$ \\
\hline Sids 12 + onion & $139 \pm 4.1^{* *}$ & $2 \pm 0.7 \mathrm{n} . \mathrm{s}$ & $17.3 \pm 4.8^{* *}$ \\
\hline Misr 2 + onion & $142.5 \pm 0.7^{* *}$ & $2.7 \pm 0.6 \mathrm{n} . \mathrm{s}$ & $21.3 \pm 4.2^{* *}$ \\
\hline Solid onion & $57 \pm 1$ & 0 & $57 \pm 0.7$ \\
\hline Solid wheat & $32.3 \pm 14$ & $1.7 \pm 0.7$ & $7.5 \pm 1.1$ \\
\hline L.S.D. 5\% & 6.50 & N.S. & 1.27 \\
\hline \multicolumn{4}{|c|}{ Second season } \\
\hline Sids 4 + onion & $183 \pm 11^{* *}$ & $6 \pm 0.5^{* *}$ & $6.3 \pm 0.8^{* *}$ \\
\hline Sids 12 + onion & $127.5 \pm 7.8^{* *}$ & $3 \pm 0.6 \mathrm{n} . \mathrm{s}$ & $21.8 \pm 4.4^{* *}$ \\
\hline Misr 2 + onion & $153.5 \pm 9.5^{* *}$ & $6 \pm 0.5^{* *}$ & $9.75 \pm 3.7^{* *}$ \\
\hline Solid onion & $19 \pm 0.4$ & 0 & $57 \pm 0.7$ \\
\hline Solid wheat & $11 \pm 0.95$ & $6 \pm 0.5^{* *}$ & 0 \\
\hline L.S.D. 5\% & 31.03 & 2.4 & 11.03 \\
\hline
\end{tabular}

It is likely that sesame attracted Nezara viridula more than cotton meaning that sesame formed biological barrier for dispersal of this insect in intercropped cotton compared with cotton solid culture. Particularly, Thangjam and Vastrad (2018) showed that sesame is attacked by different insect pests such as Nezara viridula.

Winter cropping systems (intercropping onion with wheat, solid cultures of both crops)

Winter cropping systems affected significantly insect communities in the two growing seasons except Chrysopa pallens in the first season (Table 12). The

Fayoum J. Agric. Res. \& Dev., Vol. 34, No.1, January, 2020 
Mohamed M. Lamlom ${ }^{1}$, et al.,

mean number of aphids+thrips significantly differed among cropping systems. The highest number of aphids+thrips were recorded for intercropping onion with wheat cultivar Sids 4( 166 \pm 1$)$, meanwhile the lowest values were obtained under solid cultures( $57 \pm 1$ with onion and $32.3 \pm 14$ with wheat in the first season and were $19 \pm 0.4,11 \pm 0.95$ in onion and wheat resp. in the second season. Morphophysiological changes due to growing onion with wheat increased aphids and thrips populations (Leite et al., 2005) in wheat fields. Accordingly, the lowest numbers of coccinellid beetle were recorded by intercropping onion with wheat cultivars Sids 4, whereas the highest number of coccinellid beetle was recorded by intercropping cotton with wheat cultivars Sids 12 and Misr 2 as compared to others (Table 12. This means intercropping onion with wheat early maturing cultivar Sids 4 had the lowest number of aphids but it had the highest number of thrips compared to others. It is clear that intercropping onion with wheat early maturing cultivar Sid4 played an major role in increasing number of thrips which affected negatively aphids number. Conversely, intercropping onion with wheat cultivars Sids 12 and Misr 2 resulted in increasing number of aphids which affected positively number of coccinellid beetle.

\section{Summer cropping systems (intercropping sesame with cotton, solid cultures of} both crops)

Summer cropping systems affected significantly whitefly in both seasons, meanwhile jassids, Chrysopa pallens and coccinellid beetle were affected in the second one (Table 13). The highest number of whiteflies were recorded by cotton solid culture (5.95 \pm 0.7$)$ as compared to other cropping systems. These results may be due to intercropping sesame with cotton decreased light intensity into cotton canopy which reflected negative on dry matter accumulation during growth and development. When whiteflies feed on cotton plants with a low $\mathrm{C}$ and $\mathrm{N}$ contents in tissues of intercropped cotton with sesame, they will develop more slowly on cotton plants due to in carbon deficiency and reduction in $\mathrm{N}$ per unit of leaf. Conversely, whiteflies will grow faster in leaves of cotton solid planting by feeding on stored photosynthates in leaves.

The lowest number of jassids were recorded by intercropping sesame with cotton ( $70.9 \pm 3.2$ and $94 \pm 7.0$ in the first and second seasons respectively. compared to cotton solid culture (Table 12). These results could be due to sesame used as a trap crop to reduce the pressure of jassids on cotton when compared with cotton alone.

The highest numbers of Chrysopa pallens and coccinellid beetle were recorded by intercropping sesame with cotton as compared to solid cultures of both crops (Table 13). Chrysopa pallens has efficacy in biological control of aphids, as well as other arthropod pests has been well recognized for more than 250 years (Senior and McEwen, 2001). Consequently, intercropping sesame with cotton decreased significantly number of aphids.

on the above, intensive cropping system (Onion + wheat cultivar Sids 4 / cotton + sesame) reduced insect incidence compared to the conventional cropping system (wheat / cotton).

It is important to mention that sesame may be reduced thrips in intercropped cotton fields after bulbs uprooting.

Fayoum J. Agric. Res. \& Dev., Vol. 34, No.1, January, 2020 
MAXIMIZING LAND USAGE AND PROFITABILITY BY RELAY ..........81 Table 13. Effect of summer cropping systems on insect populations (/2017 and /2018 seasons).

\begin{tabular}{|c|c|c|c|c|c|c|c|}
\hline Cropping systems & Jassids & $\begin{array}{c}\text { White } \\
\text { fly }\end{array}$ & Aphids & $\begin{array}{c}\text { Red } \\
\text { spider }\end{array}$ & $\begin{array}{c}\text { Chrysopa } \\
\text { pallens }\end{array}$ & $\begin{array}{c}\text { Coccinella } \\
\text { Butle }\end{array}$ & $\begin{array}{c}\text { Paederus } \\
\text { alfierii }\end{array}$ \\
\hline \multicolumn{7}{|c|}{ First season } \\
\hline $\begin{array}{c}\text { Intercropping } \\
\text { sesame with cotton }\end{array}$ & $\begin{array}{c}70.9 \pm 3.2 \\
\text { N.S }\end{array}$ & $4.4 \pm 0.3^{*}$ & 0 & $\begin{array}{c}0.6 \pm 0.07 \\
\text { N.S }\end{array}$ & $\begin{array}{c}0.125 \pm 0.05 \\
\text { N.S }\end{array}$ & $\begin{array}{c}0.6 \pm 0.07 \\
\text { N.S }\end{array}$ & $0.5 \pm 0.07$ N.S \\
\hline Solid cotton & $75.2 \pm 2.9$ & $5.95 \pm 0.7$ & 0 & $0.9 \pm 0.1$ & $0.125 \pm 0.05$ & $1.2 \pm 0.01$ & $0.3 \pm 0.06$ \\
\hline Solid sesame & 0 & 0 & 0 & 0 & 0 & 0 & 0 \\
\hline L.S.D. 5\% & N.S. & 1.50 & N.S. & N.S. & N.S. & N.S. & N.S. \\
\hline \multicolumn{7}{|c|}{ Second season } \\
\hline $\begin{array}{c}\text { Intercropping } \\
\text { sesame with cotton }\end{array}$ & $94 \pm 7^{* *}$. & $5.2 \pm 1.6 * *$ & 0 & 0 & $1.25+0.2 * *$ & $1.25 \pm 0.2 * *$ & $1.2 \pm 0.2 n . s$ \\
\hline Solid cotton & $237 \pm 0.5$ & $21.4 \pm 0.5$ & $0+$ & 0 & 0 & 0 & $2 \pm 0.3$ \\
\hline Solid sesame & $45 \pm 8$ & $4 \pm 0.4$ & 0 & 0 & 0 & 0 & 1 \\
\hline L.S.D. 5\% & 20.4 & 3.15 & N.S. & N.S. & 0.80 & 0.60 & N.S. \\
\hline
\end{tabular}

With respect to cotton boll worm, intercropping sesame with cotton decreased infestation of cotton boll worm (Earis insulana and Pectinophora gossypiella) as compared to cotton solid culture (Table 14). These results due to the highest numbers of Chrysopa pallens and coccinellid beetle which are considered predators for cotton boll worm. It is clear that natural enemies especially predatory insects play a significant role in reduction of bollworms larvae. Similar results were obtained by Rajput and Daware (2002) who reported that intercrops helped in the reduction of bollworm complex through the enhancement of predators like coccinellids and Chrysoperla. Also, Devi (2018) found that maximum population of Chrysoperla spp was recorded in cotton-sesame 1:1 (0.33 grubs and adults/plant) and it was at par with cotton-sesame 2:1 (0.24 grubs and adults/plant) and minimum population of Chrysoperla spp was recorded in sole cotton (0.14 grubs and adults/plant).

Table 14. Effect of intercropping sesame with cotton on cotton bollworm (2017 and 2018 seasons).

\begin{tabular}{|c|c|c|c|c|}
\hline & \multicolumn{4}{|c|}{ Mean percentage of larvae infestation } \\
\hline \multirow{2}{*}{ Cotton bollworm } & \multicolumn{2}{|c|}{ First season } & \multicolumn{2}{c|}{ Second season } \\
\cline { 2 - 5 } & $\begin{array}{c}\text { Intercropping } \\
\text { sesame with cotton }\end{array}$ & $\begin{array}{c}\text { Cotton solid } \\
\text { culture }\end{array}$ & $\begin{array}{c}\text { Intercropping } \\
\text { sesame with cotton }\end{array}$ & $\begin{array}{c}\text { Cotton solid } \\
\text { culture }\end{array}$ \\
\hline Earis insulana & 19.3 & 40.4 & 28.3 & 40.0 \\
\hline $\begin{array}{c}\text { Pectinophora } \\
\text { gossypiella }\end{array}$ & 16.7 & 18.6 & 16.7 & 20.0 \\
\hline Total & 36.0 & 59.0 & 45.0 & 60.0 \\
\hline
\end{tabular}

\section{Competitive relationships}

To assess the benefits of growing two or more crops together, or intercropping, is to measure productivity using the LER and ATER. LER compares the yields from growing two or more crops together with yields from growing the same crops in sole culture. ATER provides more realistic comparison of the yield advantage of intercropping over sole cropping in terms of variation in time taken by the component crops of different intercropping systems. Generally, the cropping system wheat cultivar Sids $4+$ onion/cotton + sesame achieved the highest LER and ATER followed by the cropping system wheat cultivar Sids $12+$ onion/cotton + sesame compared with the other cropping systems in both seasons (Table 15). Advantage of the cropping system wheat cultivar Sids 4 + onion/cotton + sesame probably attributed to this system furnished suitable ecosystem that translated into low competitive pressure between cotton for above and under-ground conditions during the year. These results are parallel with Lamlom et al. (2018) who showed that onion had higher yielding ability compared to the other crops in the cropping systems.

\section{Intercropping Economic Advantage}

Fayoum J. Agric. Res. \& Dev., Vol. 34, No.1, January, 2020 
Mohamed M. Lamlom ${ }^{1}$, et al.,

The economic performance of the intercropping was evaluated to determine if wheat + onion/ cotton + sesame combined yields are high enough for the farmers to adopt this system. The averages of monetary advantage index (MAI) values of the cropping system wheat cultivar Sids $4+$ onion/cotton + sesame were higher than the other treatments (Table 15). MAI values ranged from 8190.78 by wheat cultivar Sids 12 /cotton to 23985.16 by wheat cultivar Sids $4+$ onion/cotton + sesame in the first season. Also, MAI values ranged from 5517.81 by wheat cultivar Misr $2 /$ cotton to 21193.72 by wheat cultivar Sids $4+$ onion/ cotton + sesame in the second one. Obviously, there were gradual and consistent increase in MAI values with intercropping onion with wheat in the winter season then intercropping sesame with cotton in the summer season. These results could be due to there was an increase in total income with LER which reflected on MAI. Cropping system (wheat cultivar Sids $4+$ onion/cotton + sesame) is more profitable to Egyptian famers than the other treatments.

These results are in the same context with Lamlom et al. (2018) who reported that the intensive cropping system is more profitable to Egyptian farmers than conventional double cropping system (Egyptian clover/cotton).

\section{CONCLUSION}

It can be concluded that the intensive cropping system (wheat + onion/cotton + sesame) that involved wheat cultivar Sids 4 gave the lowest number of aphids, whiteflies and jassids in cotton crop and the highest LER, ATER and MAI compared to the other treatments in both seasons.

Table 15. Effect of wheat cultivars and cropping systems, as well as, their interaction on grain yield and its attributes (2016/2017 and 2017/2018 seasons).

\begin{tabular}{|c|c|c|c|c|c|c|c|c|c|c|c|c|}
\hline \multirow{3}{*}{\multicolumn{2}{|c|}{ Treatments }} & \multicolumn{4}{|c|}{ Yield/fad } & \multicolumn{4}{|c|}{ Relative yield } & \multirow[b]{3}{*}{ LER } & \multirow[b]{3}{*}{ ATER } & \multirow[b]{3}{*}{ MAI } \\
\hline & & \multirow{2}{*}{\multicolumn{2}{|c|}{$\begin{array}{l}\text { Winter crop } \\
\text { Wheat Onion } \\
\text { ardab ton } \\
\end{array}$}} & \multicolumn{2}{|c|}{ Summer crop } & \multicolumn{2}{|c|}{ Winter crop } & \multicolumn{2}{|c|}{ Summer crop } & & & \\
\hline & & & & $\begin{array}{l}\text { Cotton } \\
\text { kintar }\end{array}$ & $\begin{array}{c}\text { Sesame } \\
\text { ardab }\end{array}$ & Wheat & Onion & Cotton & Sesame & & & \\
\hline & & \multicolumn{11}{|c|}{ First season } \\
\hline \multirow{3}{*}{$\begin{array}{c}\text { Sids } \\
4\end{array}$} & $\mathrm{CS}_{1}$ & 17.60 & --- & 9.42 & --- & \begin{tabular}{l|l}
0.80 \\
\end{tabular} & --- & 0.90 & --- & 1.70 & 0.92 & 8573.43 \\
\hline & $\mathrm{CS}_{2}$ & 15.01 & 14.42 & 8.64 & --- & 0.68 & 0.73 & & --- & 2.24 & 1.10 & 10300.81 \\
\hline & $\mathrm{CS}_{3}$ & 16.85 & 14.42 & 8.36 & 2.12 & 0.76 & 0.73 & 0.80 & 0.52 & 2.81 & 1.30 & 23985.16 \\
\hline \multirow{3}{*}{$\begin{array}{c}\text { Sids } \\
12\end{array}$} & $\mathrm{CS}_{1}$ & .58 & --- & 9.21 & & 0.77 & --- & & $\begin{array}{ll}-- \\
\end{array}$ & 1.65 & 0.92 & 8190.78 \\
\hline & $\mathrm{CS}_{2}$ & 16.01 & 14.14 & 8.24 & $\begin{array}{ll}-- \\
\end{array}$ & 0.66 & 0.71 & 0.79 & --- & 2.16 & 1.07 & 9947.49 \\
\hline & $\mathrm{CS}_{3}$ & 3.15 & 14.14 & 7.62 & 2.08 & 0.75 & 0.71 & 0.73 & 0.51 & 2.70 & 1.27 & 22936.67 \\
\hline \multirow{3}{*}{$\begin{array}{c}\text { Misr } \\
2\end{array}$} & $\mathrm{CS}_{1}$ & 20.50 & --- & 8.97 & --- & 0.83 & --- & 0.86 & $\begin{array}{ll}-- \\
\end{array}$ & 1.69 & 0.97 & 8690.79 \\
\hline & $\mathrm{CS}_{2}$ & 19.21 & 13.57 & 7.60 & --- & 0.78 & 0.68 & 0.73 & --- & 2.19 & 1.11 & 10350.13 \\
\hline & $\mathrm{CS}_{3}$ & 9.43 & 13.57 & 7.17 & 2.10 & 0.79 & 0.68 & 0.69 & 0.51 & 2.67 & 1.28 & 22412.65 \\
\hline & & \multicolumn{11}{|c|}{ Second season } \\
\hline \multirow{3}{*}{$\begin{array}{c}\text { Sids } \\
4\end{array}$} & $\mathrm{CS}_{1}$ & 15.77 & --- & 7.49 & --- & 0.74 & --- & 0.74 & --- & 1.48 & 0.80 & 5672.45 \\
\hline & $\mathrm{CS}_{2}$ & 15.55 & 14.28 & 6.65 & --- & 0.72 & 0.75 & 0.65 & --- & 2.12 & 1.01 & 8639.53 \\
\hline & $\mathrm{CS}_{3}$ & 15.69 & 14.28 & 6.45 & 2.09 & 0.73 & 0.75 & 0.63 & 0.53 & 2.64 & 1.21 & 21193.72 \\
\hline \multirow{3}{*}{$\begin{array}{c}\text { Sids } \\
12\end{array}$} & $\mathrm{CS}_{1}$ & 18.23 & --- & 7.05 & $\begin{array}{ll}-- \\
\end{array}$ & 0.79 & --- & 0.69 & $\begin{array}{ll}-- \\
\end{array}$ & 1.48 & 0.82 & 5905.72 \\
\hline & $\mathrm{CS}_{2}$ & 16.70 & 13.64 & 6.46 & --- & 0.72 & 0.70 & 0.63 & --- & 2.05 & 1.00 & 8537.52 \\
\hline & $\mathrm{CS}_{3}$ & 17.10 & 13.64 & 6.33 & 2.03 & 0.74 & 0.70 & 0.62 & 0.52 & 2.58 & 1.19 & 21000.11 \\
\hline \multirow{3}{*}{$\begin{array}{c}\text { Misr } \\
2\end{array}$} & $\mathrm{CS}_{1}$ & 18.31 & \begin{tabular}{|l|}
--- \\
\end{tabular} & 6.88 & --- & 0.77 & --- & 0.68 & --- & 1.45 & 0.84 & 5517.81 \\
\hline & $\mathrm{CS}_{2}$ & 17.80 & 13.07 & 6.20 & --- & 0.75 & 0.67 & 0.61 & --- & 2.03 & 1.02 & 8484.76 \\
\hline & $\mathrm{CS}_{3}$ & 18.17 & 13.07 & 5.34 & 2.00 & 0.76 & 0.67 & 0.52 & 0.51 & 2.47 & 1.17 & 19262.58 \\
\hline
\end{tabular}

- Solid plantings of all crops: wheat cultivars; Sids 4: 21.92 and $21.31 \mathrm{ardab} / \mathrm{fad}, \mathrm{Sids}$ 12: 24.08 and $22.94 \mathrm{ardab} / \mathrm{fad}$ and Misr 2: 24.58 and $23.70 \mathrm{ardab} / \mathrm{fad}$; cotton: 10.38 and $10.11 \mathrm{kintar} / \mathrm{fad}$; onion: 19.72 and $19.26 \mathrm{ton} / \mathrm{fad}$ and sesame: 3.89 and $4.04 \mathrm{ardab} / \mathrm{fad}$ in the first and second seasons, respectively. And

Fayoum J. Agric. Res. \& Dev., Vol. 34, No.1, January, 2020 
- The prices of main products are L.E. 550, for ardab of wheat grain, 2400 for kintar of seed yield of cotton, 1600 for ardab of sesame and 2335for ton of grain onion respectively in 2018 season.

\section{REFERENCES}

Alston D.G. and Drost D. 2008. Onion thrips (Thrips tabaci), Utah Pests, Fact sheet, Utah State University, Utah.

Attia Zahira M. and Seif El Nasr F.M. 1993. Effect of intercropping sesame with cotton and sesame density on yield and yield components of both crops. Ann. Agric. Sci., Moshtohor, 31 (4): 1931 - 1940.

Bayhan E., Ulusoy M.R. and Brown J.K. 2006. Host range, distribution, and natural enemies of Bemisia tabaci B biotype (Hemiptera: Aleyrodidae). Turkey. J. Pest Sci., 79: 233 240.

Bonebrake T.C., Boggs C.L., McNally J.M., Ranganathan J. and Ehrlich P.R. 2010. Oviposition behavior and offspring performance in herbivorous insects: consequences of climatic and habitat heterogeneity. Oikos, 119: 927-934.

Bulletin of Statistical Cost Production and Net Return 2018. Winter field crops and vegetables and fruit. Agriculture Statistics and Economic Sector, Ministry of Egyptian Agriculture and Land Reclamation, Part (1); Egypt.

Chapman H.D. and Pratt P.E. 1961. Methods of Analysis for Soil, Plant and Water. Division Agric Sci, California Univ, U.S.A.

Devi. S. 2018. Effect of intercropping on sucking insect pests and natural enemies of cotton. Int. J. Curr. Microbiol. App. Sci., 7(4): $1101-1109$.

Donyavian H.R., Raii Y. and Jokar M. 2018. Land equivalent ratio (LER), and competition indices in cotton (Gossypium hirsutum) - sesame (Sesamum indicum) intercropping system. Egypt. Acad. J. Biolog. Sci., 11(2): 81-88.

El-Kalla,SE., A.A. Leilah, A.H. Basiony and M. Samira 1994. Effect of irrigation and foliar nutrition treatments on growth and yield of some wheat cultivarsunder El-Arish area condition. Proc. $6^{\text {th }}$ Conf. Agron. Al-Azhar Univ., Cairo Egypt,(1) 365-378.

El-Zahi E.S., Arif S.A., El-Nagar J.B.A. and El-Dewy M.E.H. 2012. Inorganic fertilization of cotton field-plants in relation to sucking insects and yield production components of cotton plants. J. American Sci., 8(2): $509-517$.

Farhat,W.Z.E.2015. Response of 21 spring bread wheat genotypes to normal and reduced irrigation in North Delta. J. of Plant production, Mansoura Univ., 6(6):943-963.

Freed R.D. 1991. MSTAT M icrocomputer Statistical - program. Michigan State Univ., EstLansing, Michigan, USA.

Gomez K.A. and A.A. Gomez 1984. Statistical Procedures for Agricultural Research, 2nd ed. John Willey and Sons, Toronto, ON, Canada.

Greene J.K., S.G. Turnipseed, M.J. Sullivan and G.A. Herzog. 1999. Boll damage by the southern green stink bug (Hemiptera: Pentatomidae) and tarnished plant bug (Hemiptera: Miridae) caged on transgenic Bacillus thuringiensis cotton.J.Econ.Entomol.92: 941 - 944.

Greenstone M.H. 2001. Spiders in wheat: First quantitative data for North America. BioControl, 46: 439-454.

Helmi A. and Rashwan Rania 2013. Effect of wheat cultivars and sown dates on aphid infestation in Egypt. Mun. Ent. Zool., 8 (2): 825 - 829.

Hiebsch C.K. 1980. Principles of Intercropping. "Effect of $\mathrm{N}$ fertilization and crop duration on equivalency ratios in intercrops versus monoculture comparisons". PhD Thesis, North Carolina State Uni., Raleigh, NC, USA.

Hussein Samira M. 2005. Planting, date, pattern and fertilizers levels for cotton grown in relay intercropping with wheat. Zagazig J. Agric. Res., 32: $1403-1425$.

Khan A.M., Khan A.A., Afzal M. and Iqbal M.S. 2012. Wheat crop yield losses caused by the aphids infestation. J. Biofertilizers \& Biopesticides 3:122.

Fayoum J. Agric. Res. \& Dev., Vol. 34, No.1, January, 2020 
Mohamed M. Lamlom ${ }^{1}$, et al.,

Lamlom M.M., Abdel-Wahab Sh.I., Abdel-Wahab T.I. and Ibrahim M.A.A. 2018. Crop interference effects of some winter and summer field crops on Egyptian cotton characters. Adv. Crop. Sci. Tech., 6: 394.

Leite G.L.D., Picanco M., Jham G.N. and Moreira M.D. 2005. Bemisia tabaci, Brevicoryne brassicae and Thrips tabaci abundance on Brassica oleracea var. acephala. Pesquisa Agropecuária Brasileira, 40: 197 - 202.

Mead R. and Willey R.W. 1980. The concept of a "land equivalent ratio" and advantages in yields from intercropping. Exp. Agric., 16: 217 - 228.

Metwally A.A., Abuldahab A.A., Shereif M.N. and Awad M.M. 2016. Productivity and land equivalent ratio of intercropping cotton with some winter crops in Egypt. American J. Exp. Agric., 14: $1-15$.

Abd. El-Fatah,Nagwa,R.1995. Effect of fertilization on growth, yield and some technological characteristics of some new bread wheat cultivars. Ph.D. Thesis Fac. Agric., Moshtohor, Zagazig Univ. Egypt.

Naroz Magda H., Abdel-Wahab Eman I., Saied Sawsan M., Taha A.M. and Abdel-Wahab Sh.I. 2018. Response of soybean insect communities to different plant densities of some soybean varieties under two cropping systems. Soybean Res., 16 (1\&2): 78-107.

Patterson R. and Ramirez R. 2016. Aphid Natural Enemies and Biological Control. Utah State University Extension and Utah Plant Pest Diagnostic Laboratory, March 2016.

Rafee C.M. 2010. Insect pest management in desi cotton. Ph.D. Thesis submitted to Department of Agricultural Entomology, College of Agriculture, Dharwad University of Agricultural Sciences, Dharwad, Karnataka.

Rajput K.P. and Daware, D.G. 2002. Effects of different intercrops on the population buildup of Chrysoperla and coccinellids on cotton. Journal of Cotton Research and Development, 16:106 - 107.

Rodrigues D., Kaminski L.A., Freitas A.V.L. and Oliveira P.S. 2010. Trade-offs underlying polyphagy in a facultative ant-tended florivorous butterfly : the role of host plant quality. Oecologia, 163: 719-728.

Safdar M.Z., Naeem M., Rashid M. and Niaz U. 2019. Effect of abiotic factors on population dynamics of whitefly and jassid on Bt cotton. Curr. Inves. Agri. Curr. Res., 6 (1): 695 -698 .

Samier,K.A.Ismail 2015. Heterosis and Combining Ability for yield and its components in bread wheat ( Triticum aestivum L.). Int. J. Curr. Mierobiol. App. 4(8): 1-9.

Senior L.J. and McEwen P.K. 2001. The use of Lacewings in Biological Control. In: Lacewings in the Crop Environment, McEwen, P.K., T.R. New and A.E. Whittington (Eds.). Cambridge University Press, Cambridge, pp: $296-302$.

Sherif Sahar A., Ibrahim Sahar T. and Mohamed Wafae Kh. 2011. Relay intercropping of cotton with wheat in reclaimed land. Egypt. J. Agron.33 (1): $51-65$.

Thangjam Rojeet and Vastrad A.S. 2018. Studies on pest complex of sesame and their natural enemies in North Karnataka, India. J. Entomol. and Zool. studies, 6(6): 57 - 60.

Toaima S.E., Gadallah R.A. and Mohamadin E.S.A. 2007. Effect of relay intercropping systems on yield and its components of wheat and cotton. Ann. Agric. Sci., 52 (2): $317-326$.

Tulli María C., Carmona D.M. and Vincini Ana M. 2013. Influence of plant diversity on the numerical response of Eriopis connexa (Coleoptera: Coccinellidae) to changes in cereal aphid density in wheat crops. Int. J. Ecology, Volume 2013, Article ID 789532.

Wang, W.L. 2008. The control effect of wheat biodiversity on wheat field. Master's Thesis, Shandong Agricultural University, Tai'an, China, 2008.

Willey R.W. 1979. Intercropping, its importance and research needs. Part 1; competition and yield advantages. Field Crops Abst., 32:1 - 10.

Fayoum J. Agric. Res. \& Dev., Vol. 34, No.1, January, 2020 
تعظيم استخدام الأرض وربحيتها من خلال التحميل المناوب للقطن مع بعض المحاصيل وعلاقته بالإصايه الحشريه

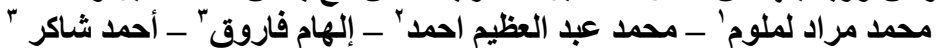

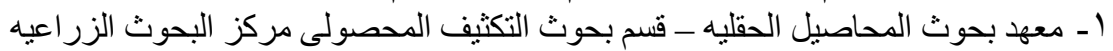

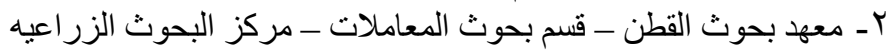

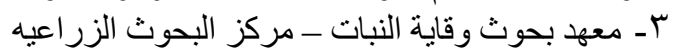

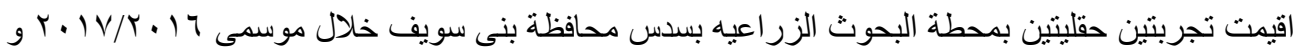

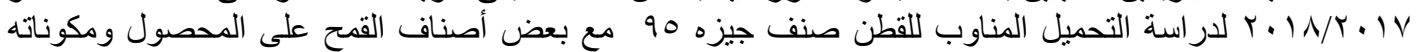

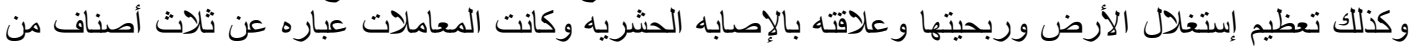

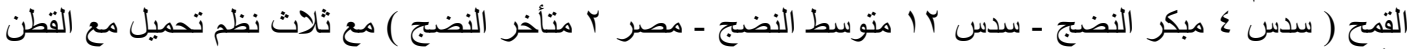

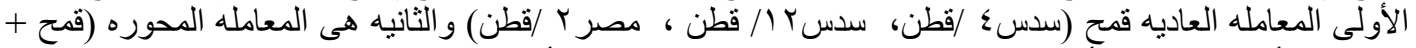

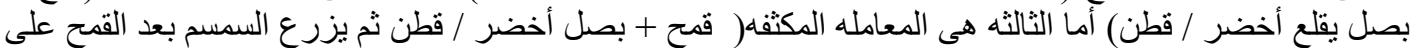

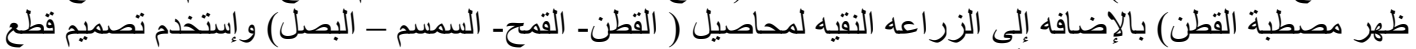

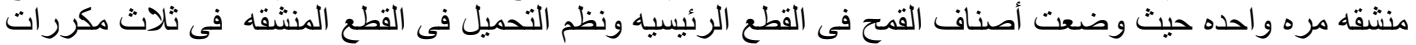

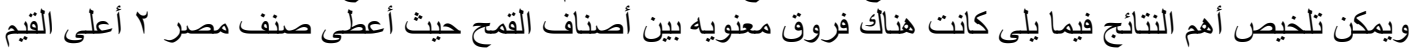

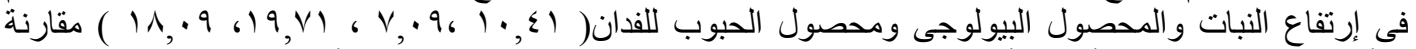

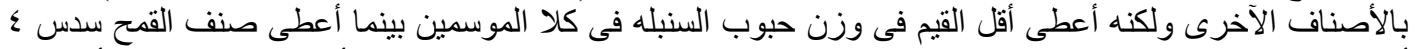

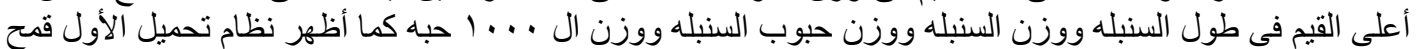

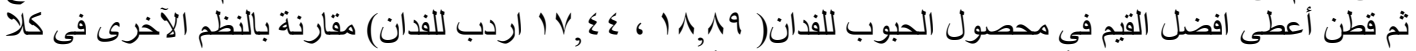

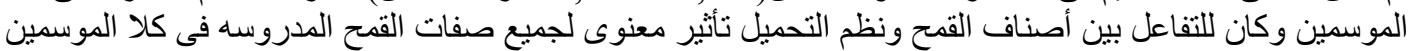

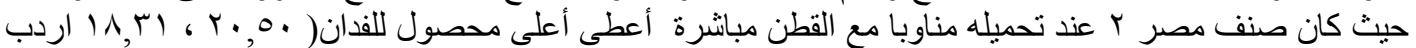

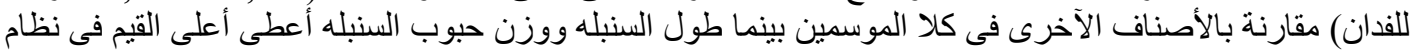

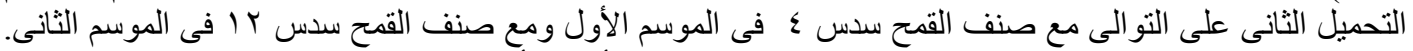

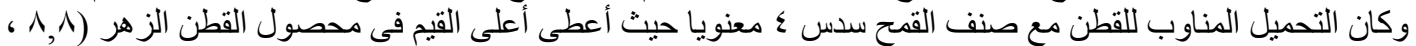

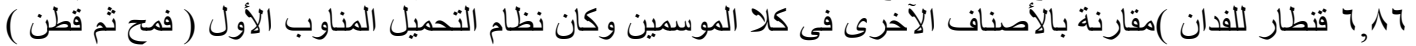

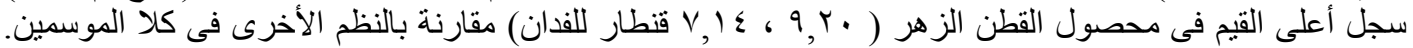

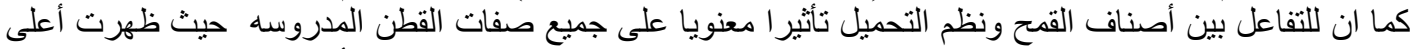

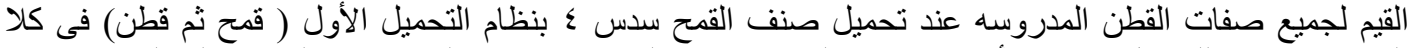

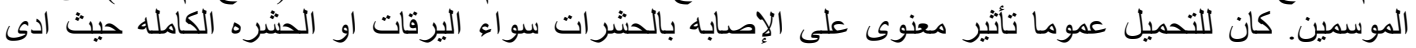

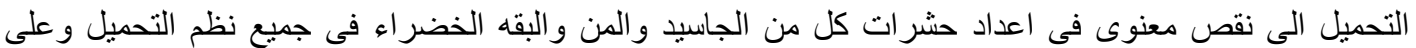

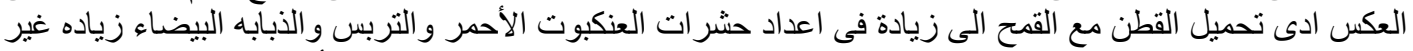

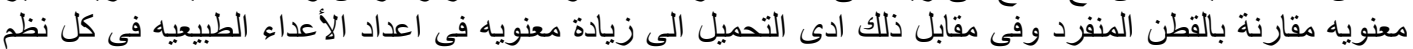

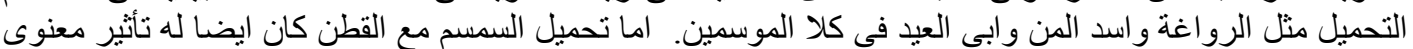

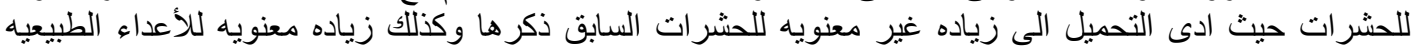

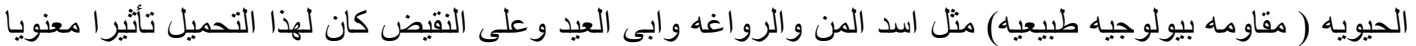

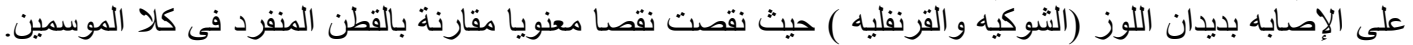

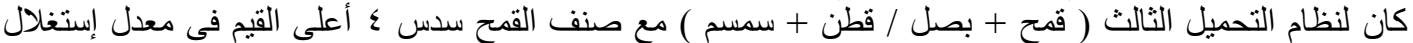

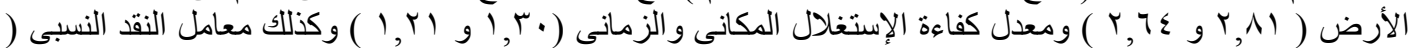

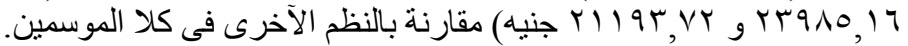
نظم تحميل - قمح - بصل - قطن - سمسم - الإصـابه الحثرية ـ العلاقات التنافسيه - ربحية المزارع

Fayoum J. Agric. Res. \& Dev., Vol. 34, No.1, January, 2020 